\title{
New records of Campsomeris servillei (Guérin-Méneville, 1831) (Hymenoptera: Scoliidae) and actual distribution in Chile
}

\section{Nuevos registros de Campsomeris servillei (Guérin-Méneville, 1831) (Hymenoptera: Scoliidae) y actual distribución en Chile}

\section{Jaime Pizarro-Araya ${ }^{1, *}$, Fermín M. Alfaro1,2, Macarena González-Dossi ${ }^{3}$ \& José Mondaca ${ }^{4}$}

\author{
${ }^{1}$ Laboratorio de Entomología Ecológica (LEULS), Departamento de Biología, Facultad de Ciencias, Universidad de La Serena, Casilla 554, La Serena, Chile. \\ IInstituto de Investigación Multidisciplinar en Ciencia y Tecnología, Universidad de La Serena, Casilla 554, La Serena, Chile. \\ ${ }^{3}$ Carrera de Ingeniería Agronómica, Escuela de Agronomía, Facultad de Ciencias, Universidad de La Serena, Casilla 554, La Serena, Chile. \\ ${ }^{4}$ Servicio Agrícola y Ganadero (SAG), Camino La Pólvora s/n, Valparaíso, Chile. \\ *E-mail: japizarro@userena.cl
}

\begin{abstract}
The family Scoliidae is a group of wasps that are parasitoids of scarab beetle larvae and are important biological controllers. In Chile this group is underrepresented and has no clear distribution. The aim of this short communication is to report new records and update the current distribution of the scoliid wasp Campsomeris servillei (Guérin-Méneville). We also discuss probable distribution scenarios for northern Chile as well as some aspects of the biology and ecology of these wasps.

Keywords: Campsomerini, naturalized species, Neotropical region, Scoliinae, semiarid, transverse valleys.

RESUMEN

La familia Scoliidae es un grupo de avispas que parasitan larvas de escarabeidos y son importantes controladores biológicos. En Chile, este grupo está poco representado y no tiene una distribución clara. El objetivo de esta comunicación breve es entregar nuevos registros y actualizar la distribución actual de la avispa escólida Campsomeris servillei (Guérin-Méneville). Se discuten los probables escenarios de distribución para el norte de Chile, así como algunos aspectos de la biología y ecología de estas avispas.

Palabras clave: Campsomerini, especies naturalizadas, región Neotropical, Scoliinae, semiárido, valles transversales.
\end{abstract}

Scoliids are characterized by possessing a strong, pilous body; eyes markedly emarginate; metasternum extended in a broad plate overlapping the posterior coxae; anterior wing ends adorned with profuse lines and fake veins; the real veins do not extend up to the wing apex (Argaman 1996). As these wasps are parasitoids of Scarabaeidae (Coleoptera) larvae (Inoue \& Endo 2006, Grissel 2007), they are considered to be important biological controllers. The females dig the soil in search for larvae and then they sting the larva to paralize it and lay a single egg inside it (Abbate et al. 2018).
The family Scoliidae, which is widely distributed all over the world, currently includes four subfamilies -Campsomerinae, Colpinae, Proscoliinae, and Scoliinae- and its complex nomenclature has been subject to many changes (Argaman 1996). Campsomerini is one of two tribes in the subfamily Scoliinae, with the other being Scoliini. As of this writing, the tribe Campsomerini includes the genera Campsomeris GuérinMéneville, 1839, Pygodasis Bradley, 1957, Rhabdotomeris Bradley, 1957, Stygocampsomeris Bradley, 1964, Hayderiba Argaman, 1996, and Tatusdayca Argaman, 1996. 


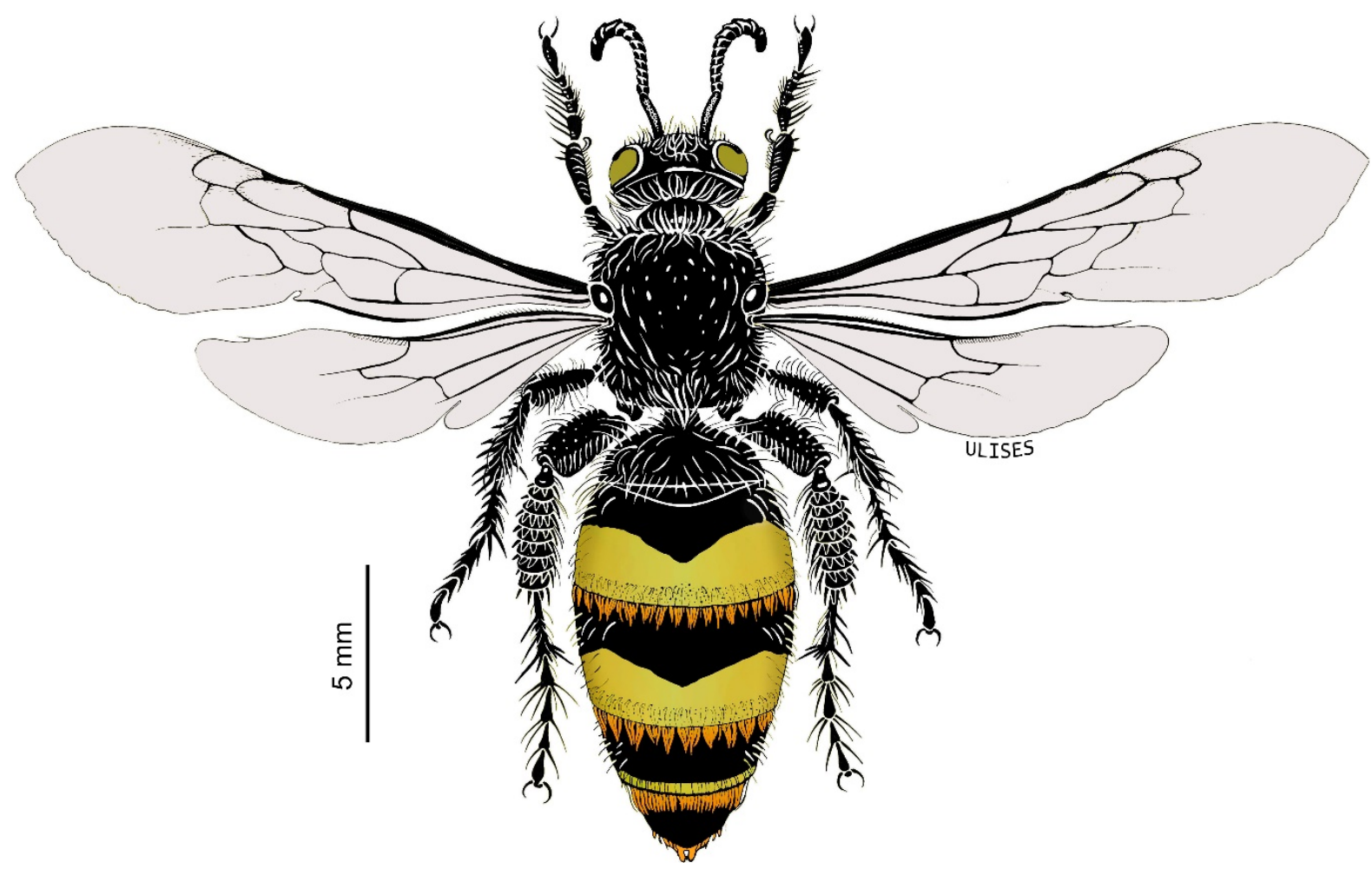

Figure 1. Campsomeris servillei (Guérin-Méneville, 1831) (Hymenoptera: Scoliidae). Drawing of the dorsal view of a female. / Dibujo de la vista dorsal de una hembra.

In Chile, this tribe is represented exclusively by Campsomeris servillei (Guérin-Méneville, 1831) (Fig. 1), a species reported only in the north of Azapa and Lluta (Arica y Parinacota) (Aguilera 1968).

Due to the limited records of this wasp, we update the distribution of $C$. servillei with new records for northern and central Chile. All the studied specimens are deposited in the entomological collection of the Laboratorio de Entomología Ecológica of the Universidad de La Serena, Chile (LEULS, Jaime Pizarro-Araya) and the Entomology section of the National Museum of Natural History, Santiago, Chile (MNNC, Mario Elgueta). The specimens' identification follows Bradley $(1945,1957)$. Campsomeris, with Scolia atrata Fabricius, 1775 , as a type species, is characterized by a recurrent second vein present (Fig. 2a) The female has the longest spur of the posterior tibia long and thin, 64 to $80 \%$ of the length of the metatarsal; vertex and dorsal area usually roughly screened; base of mid-dorsal propodeum with a fuzzy area without punctuation, bordered posteriorly by a row of firm, erect eyelashes (Figs. 2a, 2b). The male has hyaline wings or slightly tinged with yellowish brown with the entire wing membrane with setae (Figs. 2c, 2d).

The examined material was captured in the following localities: Chile: Arica and Parinacota Region: Arica. I.1929.
19 (MNNC). Arica. 20.I.1970. 20 (MNNC). Lluta. 20.I.1970. 19 (MNNC). Lluta Km. 7. 27.XI.1960. col. G. Díaz en alfalfa. $1{ }^{\lambda}$ (MNNC). Lluta, Campex. sept 1967. col. A. Aguilera and G. Díaz. 19 (MNNC). Azapa Grande. VII.1966. col. G.

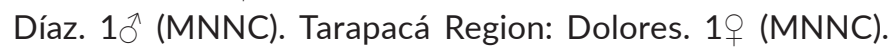
Tarapacá, I. Reg., V. La Frontera. III.1988. col. T. Fichet. 10 (MNNC). Pica. 1995. leg. M. Medina. 1 (MNNC). Iquique. 9.IV.1955. 10 (MNNC). Coquimbo Region: Maquipalli, La Serena. 2.VI.2017. col. M. González Dossi. 1§̋/4 (LEULS). Maquipalli, La Serena, 2.VI.2017. col. J. Pizarro-Araya and F.M. Alfaro. 19 (LEULS). Maquipalli, La Serena. 4.I.2020. col. M. González-Dossi. 3ð̄ (LEULS).

The new records for the region of Coquimbo encompass the southernmost part of the species' known distribution range for Chile. The specimens were found in agricultural plots located in the lower section of the Elqui basin (region of Coquimbo), an area formed by fluvial-marine terraces. In this area, the average annual rainfall is approximately $104 \mathrm{~mm}$, being June the wettest month with $25.9 \mathrm{~mm}$. The dry season lasts nine months, and the average monthly temperature stays above $10^{\circ} \mathrm{C}$ throughout the year (Novoa \& Villaseca 1989). The area is covered with a wide variety of crops, including vegetables such as potato (Solanum tuberosum Linnaeus), and squash (Cucurbita spp.), and home garden 

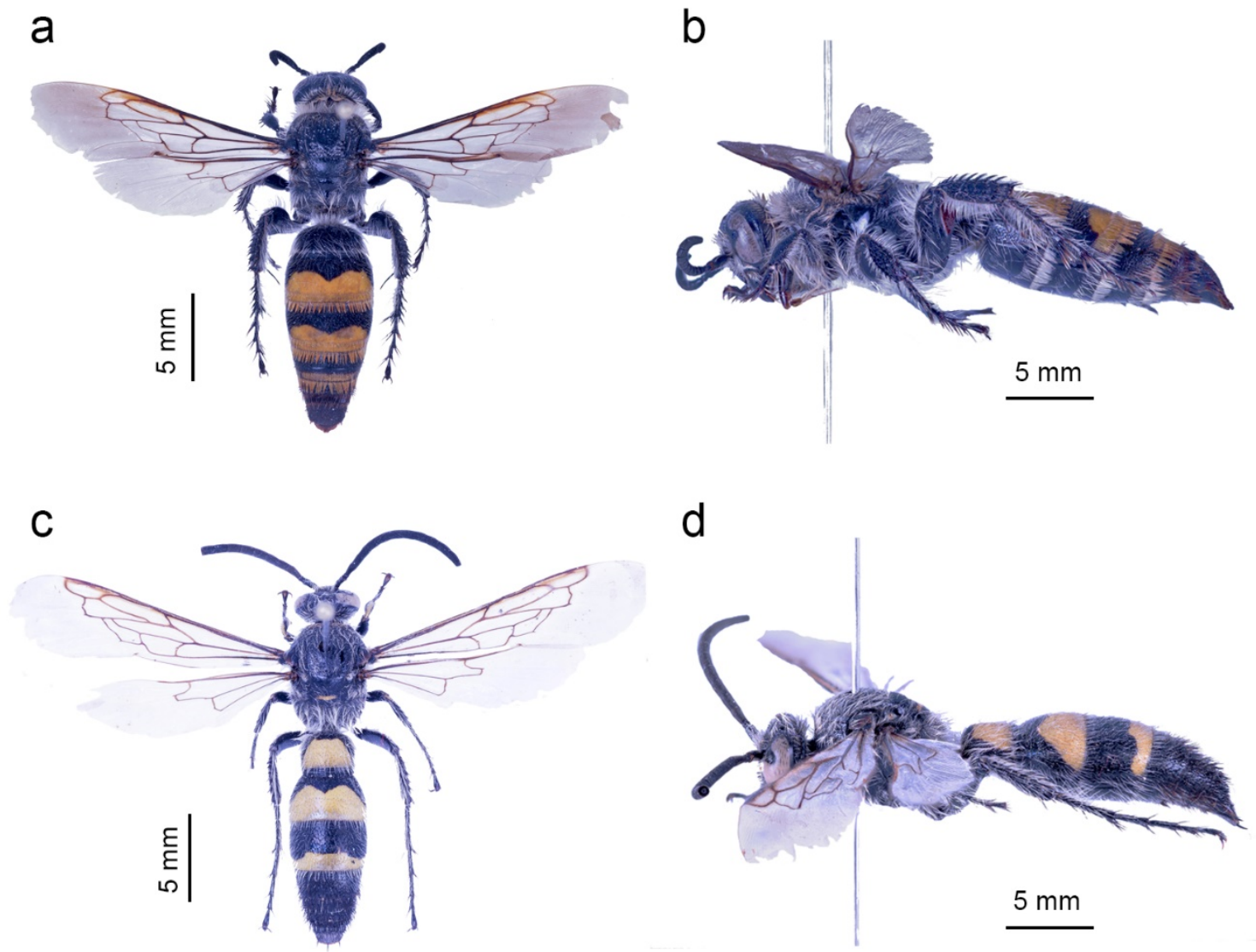

Figure 2. Campsomeris servillei (Guérin-Méneville, 1831) (Hymenoptera: Scoliidae) a) Habitus dorsal view of the female; b) Habitus lateral view of the female; c) Habitus dorsal view of the male; d) Habitus lateral view of the male. / Campsomeris servillei (GuérinMéneville, 1831) (Hymenoptera: Scoliidae) a) Habitus vista dorsal de la hembra; b) Habitus vista lateral de la hembra; c) Habitus vista dorsal del macho; d) Habitus vista lateral del macho.

fruits such as quince (Cydonia oblonga Miller), peach (Prunus persica L. Batsch), apple (Malus domestica Borkh), pear (Pyrus communis Linnaeus), and several citrus species.

The C. servillei records reported here are widely distributed in most of northern Chile (Fig. 3), an area encompassing the biogeographical provinces of Atacama and Coquimbo, which are part of the South American transition zone and the central Chilean subregion, respectively (Morrone 2015). C. servillei may also occur in the transverse valleys of the semiarid region of Chile, though there are no records of this species as of yet in Copiapó and Huasco (region of Atacama). Based on the absence of records for this species in natural dryland environments, we believe that it is unlikely that this species could survive in the dry conditions of the Atacama Desert (Pizarro-Araya et al. 2009, 2019, 2021). Considering the wide distribution of this species in the neotropical region, the introduction of this wasp may be a result of the continuous flow of agricultural and horticultural products mainly from Peru (Arequipa,
Moquegua, and Tacna valleys) and Arica (Azapa and Lluta valleys). It should be noted that the records for Coquimbo were located in areas near the La Palmera Farming and Fishing Terminal (La Serena, region of Coquimbo), a high commercial-flow distribution center for fruits and vegetables brought from northern Chile and southern Peru.

The genus Campsomeris is widely distributed worldwide and is more diverse in the tropics and subtropics of the Old World. In the Americas it is distributed from the United States to Argentina, though most of its species are found in South America (Lazell 2005). Since all the members of this group are believed to use scarabid beetle larvae as hosts for their own larvae (Kurczewski 1963), the use of paralizing venom has been discussed in several studies (Piek \& Spanjer 1986, Piek et al. 1987). Based on its wide distribution, this group has been used as a biological controller. One example is Campsomeris dorsata (Fabricius, 1787), a wasp endemic of South America, Central America and the West Indies that has quickly established in Florida, United States, since its 
introduction in 1930 (Abatte et al. 2018). However, other efforts, such as the introduction of Campsomeriella collaris quadrifasciata (Lepeletier, 1845) (as Campsomeris aureicollis Lepeletier, 1935) in cane fields of Australia (López 1933), have been unsuccessful. As for C. servillei, it has been used to control larvae of Podischnus agenor (Olivier, 1789) (Coleoptera: Scarabaeidae), a pest species in sugarcane fields in Venezuela (Narváez 2003). Although the available biological-bionomical and ecological data for this species are limited, Elliot (1990) points out that for Campsomeris trifasciata (Fabricius, 1793), the females of the species are

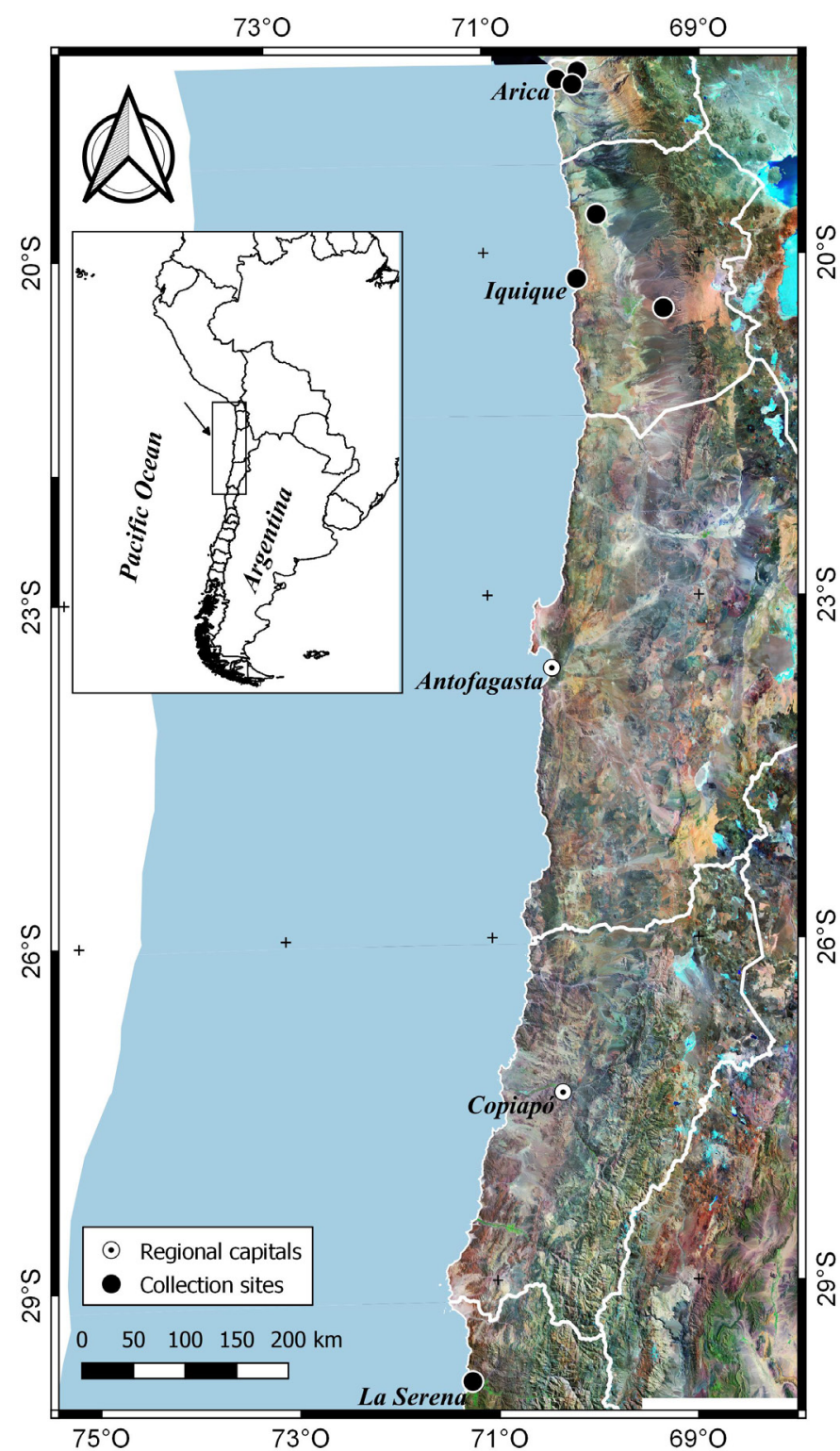

Figure 3. Records of Campsomeris servillei (Guérin-Méneville, 1831) (Hymenoptera: Scoliidae) for Chile. / Registros de Campsomeris servillei (Guérin-Méneville, 1831) (Hymenoptera: Scoliidae) para Chile. more frequent flower visitors compared to males. These visits may be aimed at collecting nectar to compensate for the individuals' high energy expenditure (Minagi et al. 2000, Inoue \& Endo 2006).

There is no data available to assess the agricultural significance of this species in Chile. According to Norambuena \& Aguilera (1988), the scarabid species that are more harmful to agriculture (prairies and cereal fields) in Chile include Hylamorpha elegans (Burmeister, 1844), Phytoloema herrmanni (Germain 1901), and Sericoides germaini Dalla Torre 1912, all of which represent significant pests between the regions of El Maule and Los Lagos. Based on the data reported in this study, C. servillei has been found to attack large scarabid species (Narváez 2003). For this reason, it is necessary to study the potential predation of large species inhabiting the northernmost part of Chile, such as Golofa minutus Sternberg, 1910; Tomarus maimon Erichson, 1847; T. rostratus Dupuis, 2014, and Archophileurus chaconus (Kolbe, 1910), as well as other smaller ones such as Liogenys GuérinMéneville, 1831 or Ligyrus villosus (Burmeister, 1847), distributed in the region of Coquimbo. More data about the biology, ecology and behavior of this species are needed to better understand its dispersion ability and wide distribution range.

\section{ACKNOWLEDGMENTS}

Our thanks to Mario Elgueta for allowing us access to the scoliid material of the MNNC. We also would like to thank Luis Letelier for providing SIG assistance (Universidad de Talca), Ulises López for the scientific illustration (https:// instagram.com/naturaloza), Álvaro Salazar (Universidad de La Serena) for the photographs of the collected material, Alberto Castex by its photography assistance (https:// fundacion-indomita.org/) and to Lucía Dossi Osorio for his help in the study sites. This study was funded by DIDULS project PR2121210 of Universidad de La Serena, La Serena, Chile.

\section{REFERENCES}

Abbate, A., Campbell, J., Bremer, J., Kern, W.H. 2018. The Introduction and Establishment of Campsomeris dorsata (Hymenoptera: Scoliidae) in Florida. Florida Entomologist 101: 543-545.

Aguilera, A. 1968. La colección de insectos del Centro de Investigación y Capacitación Agrícola (CICA) - Arica. Revista de la Universidad del Norte 2: 3-14. 
Argaman, Q. 1996. Generic synopsis of Scoliidae (Hymenoptera, Scolioidea). Annales Historico-Naturales Musei Nationalis Hungarici 88: 171-222.

Bradley, J.C. 1945. The Scoliidae (Hymenoptera) of Northern South America, with special reference to Venezuela. I. The genus Campsomeris. Boletín de Entomología Venezolana 4: 1-36.

Bradley, J.C. 1957. The Taxa of Campsomeris (Hymenoptera: Scoliidae) Occurring in the New World. Transactions of the American Entomological Society 83: 65-77.

Elliott, N.B. 1990. Flower-feeding activities of Campsomeris trifasciata nassauensis Bradley (Hymenoptera: Scoliidae). Proceedings of the Symposium on the Botany of the Bahamas 3: 1-6.

Grissell, E.E. 2007. Scoliid Wasps of Florida, Campsomeris, Scolia, and Trielis spp. (Insecta: Hymenoptera: Scoliidae). Featured Creatures, DPI Entomology Circulars 179.

Inoue, M., Endo, T. 2006. Spatiotemporal distribution and resource use of scoliid wasps (Hymenoptera) in coastal sand dunes. Entomological Science 9: 359-371.

Kurczewsky, F.E. 1963. Biological notes on Campsomeris plumipes confluenta (Say) Hymenoptera: Scoliidae). Entomological News LXXIV: 21-24.

Lazell, J.D. 2005. Island: fact and theory in natura. University of California Press. 402 pp.

Lopez, A.W. 1933. II. Progress report on the exchange of Scoliid wasps with Australia. International Society of Sugar Cane Technologists. Bulletin 50: 6-9.

Minagi, K., Maeta, Y., Kitamura, K. 2000. Studies on the conservation of pollination ecosystem in sand dune 1. Pollinators and their seasonal fluctuation at the Taisya sand dune in San-in district. Bulletin of Hoshizaki Green Foundation 4: 139-160.

Morrone, J.J. 2015. Biogeographical regionalization of the Andean region. Zootaxa 3936: 207-236.
Narváez, Z. 2003. Entomofauna agrícola venezolana. Universidad Central de Venezuela. Facultad de Agronomía. Departamento de Zoología Agrícola. Fundación Polar, Maracay, estado Aragua, Venezuela. URL: http://www. ucla.edu.ve/dagronom/departamentos/ciencias_ biologicas/entomologiaEconomica/entomofaunaven.pdf. Accessed: April 14, 2021.

Norambuena, H., Aguilera, A. 1988. Plagas de las praderas. In: I. Ruiz (Ed) Praderas para Chile: 223-248. Instituto de Investigaciones Agropecuarias, Santiago Chile.

Novoa, R., Villaseca, S. 1989. Mapa Agro-climático de Chile. Ediciones Instituto de Investigaciones Agropecuarias, INIA, Ministerio de Agricultura, Santiago, Chile. 221 pp.

Piek, T., Spanjer, W. 1986. Chemistry and pharmacology of solitary wasp venoms. In: Piek, T. (Ed.) Venoms of the Hymenoptera: 161-307. Academic Press, London.

Piek, T., Hue, B., Pelhate, M., Mony, L. 1987. The venom of the wasp Campsomeris sexmaculata (F.) blocks synaptic transmission in insect CNS. Comparative Biochemistry and Physiology - Part C: Toxicology \& Pharmacology 87: 283-286.

Pizarro-Araya, J., Cepeda-Pizarro, J., Barriga, J.E., Bodini, A. 2009. Biological vulnerability in the Elqui Valley (Coquimbo Region, Chile), to economically important arthropods. Ciencia e Investigación Agraria 36: 215-28.

Pizarro-Araya. J., Alfaro, F.M., Muñoz-Rivera, R.A., Barriga-Tuñon, J.E., Letelier, L. 2021. Arthropods of the Limari River basin (Coquimbo Region, Chile): taxonomic composition in agricultural ecosystems. Revista de la Facultad de Ciencias Agrarias 53: 245-253.

Pizarro-Araya, J., Alfaro, F.M., Muñoz-Rivera, R.A., Barriga, J.E., Letelier, L., Tirado, C. 2019. Distribución espacial de artrópodos en agroecosistemas de la cuenca del río Limarí (Región de Coquimbo, Chile). Revista de Geografía Norte Grande 72: 133-144.

Received: 13.07.2020

Accepted: 30.04.2021 